\title{
DISPENSASIONALISME SEBAGAI METODE DALAM MEMAHAMI ALKITAB
}

\author{
Philip Suciadi Chia ${ }^{1)}$ Juanda $^{2)}$ \\ 1) Southern Baptist Theological Seminary - Kentucky USA \\ E-mail: pchia275@students.sbts.edu \\ 2) Evangelical Theological Seminary of Indonesia - Surabaya \\ E-mail: juanda@sttii-surabaya.ac.id
}

\begin{abstract}
The Bible is the word of God that needs to be understood by all those who already have Jesus as their personal Lord and Savior. This is called a Christian. It is different from people who are Christians as a 'religion'. Christians are obliged to study the Bible as a basic truth in order to know God's will from time to time On the other hand, Bible learners often experience confusion problems, when understanding the continuity of the contents from Genesis to Revelation. Are there interrelations? Or it is just a fragmented story with different intentions. There are appropriate methods in avoiding confusion when doing this learning process. This method has been understood since the beginning of the century which then became popular throughout the world in the 19th century, with the term Dispensationalism. Dispensation is a period of time during which humans are tested in the perspective of obedience to a specific revelation of God's will. Theologically, the word dispensation means a religious system that is understood as a divine provision or as a sign of progressive revelation that expresses the changing needs of an individual nation or time period. Dispensationalism views the world as a household run or worked by God. Dispensation theology is often misunderstood by theologians, without wanting to study it carefully, where is the oddity? This discussion will show that Dispensationalism is as a sharp knife for understanding the Bible as a whole.
\end{abstract}

Keywords: Dispensationalism, Theology Dispensationalism, Oikonomia,

\begin{abstract}
Abstrak
Alkitab itu firman Allah yang perlu dipahami oleh semua orang yang telah memiliki Yesus sebagai Tuhan dan Juruselamatnya secara pribadi. Ini disebut orang Kristen. Beda dengan orang yang 'beragama' Kristen. Orang Kristen itu hukumnya wajib, untuk mempelajari Alkitab, sebagai dasar kebenaran dalam rangka mengetahui kehendak Allah dari zaman ke zaman. Di sisi lain, para pembelajar Alkitab sering mengalami kendala kebingungan, saat memahami kesinambungan dari isi Kitab Kejadian hingga Kitab Wahyu. Apakah ada saling keterkaitannya? Ataukah hanya kisah yang terpotong-potong dengan maksud yang berbeda-beda. Ada metode yang tepat guna dalam menghindarkan diri dari kebingungan saat melakukan proses pembelajaran ini. Metode ini telah dipahami sejak abad permulaan yang kemudian mulai populer ke seluruh dunia pada abad 19, dengan istilah Dispensasionalisme. Dispensasi merupakan suatu periode waktu di mana pada masa itu manusia diuji di dalam perspektif ketaatan kepada suatu wahyu spesifik dari kehendak
\end{abstract}


Allah. Secara teologis kata dispensasi berarti sistem religius yang dipahami sebagai suatu ketetapan ilahi atau sebagai penunjuk cara pewahyuan secara progresif yang mengekspresikan perubahan kebutuhan bangsa secara individu atau periode waktu. Dispensasionalisme memandang dunia sebagai rumah tangga yang dijalankan atau dikerjakan oleh Allah.Teologi Dispensasi sering disalahmengerti oleh para teolog, tanpa mau mempelajari terlebih dahulu dengan teliti, di mana letak kejanggalannya? Pembahasan ini akan menunjukkan bahwa Dispensasionalisme merupakan pisau yang tajam untuk memahami Alkitab secara utuh.

Kata Kunci: Oikonomia, Dispensasionalisme, Teologi Dispensasi.

\section{PENDAHULUAN}

Kata dispensasi merupakan bentuk ungkapan dari bahasa Latin dispensatio di mana Vulgata memakainya untuk menerjemahkan kata Yunani oikonomia. ${ }^{1}$ Bentuk feminim dari oikonomia memiliki beberapa pengertian yakni mengatur rumah tangga namun bisa juga berarti susunan, pesanan dan rencana. Sedangkan dalam bentuk maskulinnya dapat diartikan sebagai seseorang yang berperan sebagai atasan atau melayani sebagai pelayan rumah tangga. $^{2}$ Kata oikonomia itu sendiri merupakan gabungan dari kata Yunani yakni oikos (rumah) dan nemo (membagi, mengatur atau membagi kekuasaan), yang dapat diartikan sebagai "penatalayanan". Kata ini digunakan di dalam Lukas 16:2; 3; 4; 1 Korintus 9:17; Efesus 1:10; 3:2; 9; Kolose 1:25 dan 1 Timotius 1:4. ${ }^{3}$ Arti secara umum, dispensasi adalah sebuah administrasi atau manajemen dari sebuah urusan rumah tangga oleh seorang pelayan atau atasan.

Secara teologis kata dispensasi berarti sistem religius yang dipahami sebagai suatu ketetapan ilahi atau sebagai

${ }^{1}$ Eddy Peter, Teologi Perjanjian Versus Dispensasionalisme (Tangerang: STT International Philadelphia, 2004), 8.

${ }^{2}$ J.H Moulton and George Milligan, The Vocabulary of the Greek Testament (Grand Rapids: Wm. B. Eerdmans Publishing Co., 1949), 442-443. penunjuk cara pewahyuan secara progresif yang mengekspresikan perubahan kebutuhan bangsa secara individu atau periode waktu. ${ }^{4}$ Dari sudut pandang teologi, dispensasi dapat diartikan sebagai "suatu pemisahan ekonomi dalam melaksanakan tujuan Allah". 5

\section{DEFINISI TOKOH}

Scofield mengemukakan bahwa dispensasi merupakan suatu periode waktu di mana pada masa itu manusia diuji di dalam perspektif ketaatan kepada suatu wahyu spesifik dari kehendak Allah. Luis Chafer mengatakan bahwa dispensasi dapat diartikan sebagai penunjuk wahyu progresif dari ketetapan Allah sebagai ciri khas dari kehidupan pelayanan atau pemerintahan. Ryrie menjelaskan bahwa dispensasi merupakan pembedaan ekonomi di dalam tujuan dari karya kerja Allah. Dispensasionalisme memandang dunia sebagai rumah tangga yang dijalankan atau dikerjakan oleh Allah. Di dalam rumah tangga-Nya, Allah membagi atau mengatur persoalan-persoalan yang terdapat di

\footnotetext{
${ }^{3}$ Paul Enns, The Moody Handbook of Theology 2 (Malang: SAAT, 2004), 156.

4 The Oxford English Dictionary (Oxford University Press, 1933), III, 481.

${ }^{5}$ Enns, The Moody Handbook of Theology 2, 157.
} 
dalamnya berdasarkan kehendak-Nya dan di dalam tahap-tahap yang berbeda dari pewahyuan di dalam masing-masing waktu. Tahap-tahap yang berbeda ini ditandai dengan pembedaan ekonomi yang berbeda di dalam pekerjaan-Nya dari seluruh maksud-Nya dan perbedaan ekonomi ini terdapat di dalam dispensasi. Pengertian ilahi akan pembedaan ekonomi merupakan hal yang esensial untuk mengintepretasi Kitab Suci secara layak dari Wahyu-Nya dengan sejumlah ekonomi yang berbeda. ${ }^{6}$

Dallas Theological Seminary, yang beraliran Dispensasionalisme, mengemukakan pandangannya dalam Statement of Faith:

"Kami percaya bahwa
dispensasi merupakan
penatalayanan dari Allah
yang mengelola atau
menjalankan tujuan-Nya di
dunia dalam pelbagai
tanggung-jawab. $\quad$ Kami
percaya bahwa perubahan di
dalam dipensasi dari Allah
kepada manusia bergantung
kepada perubahan kondisi
ataupun situasi manusia yang
berada di dalam relasi dengan
Tuhan dan perubahan ini
merupakan hasil dari
kegagalan manusia dan
penghakiman Allah. Kami
percaya bahwa perbedaan
tanggung-jawab ram dalam
mengatur merupakan bagian
dari karakter Allah yang
dimanifestasikan di dalam
tulisan Alkitab, dalam
seluruh rentang waktu dari
sejarah manusia dan pada
akhir dari masing-masing
bagian terdapat akan

\footnotetext{
${ }^{6}$ Charles C. Ryrie, Dispensationalism Today (Chicago: Moody Press, 1965), 29-30.

${ }^{7}$ Dallas Theological Seminary 2007-2008 Catalog, 188.
}

kegagalan manusia di dalam
ujian ketaatan dan
$\begin{aligned} & \text { penghakiman Allah di } \\ & \text { dalamnya". }\end{aligned}$

Dengan demikian, dispensasional merupakan suatu periode waktu di mana dalam tiap-tiap periode waktu tertentu, manusia diuji untuk bertanggung-jawab terhadap wahyu tertentu dari Allah.

\section{SEJARAH}

Para teolog Covenant Theology mengecam bahwa Dispensasionalisme bukanlah pengajaran dari para rasul karena ajaran ini baru muncul pada permulaan abad 19. C.B. Bass bahkan dengan tegas mengemukakan, "Dispensasionalisme bukanlah pengajaran para rasul, apalagi bila dilihat dari sudut pandang eskatologi. Mereka menganut dan mengajarkan pretibulation $^{8}$ yang sama sekali para rasul tidak pernah ajarkan.

Jadi pretribulation merupakan ajaran Dispensasi.

Bahkan banyak kalangan juga yang mengatakan bahwa Dispensasionalisme tidak berasal pula dari zaman bapa-bapa gereja bahkan tidak alkitabiah.

Dispensasionalisme secara resmi memang lahir pada permulaan abad 19 di Inggris dalam gerakan Brethen yang akhirnya membawa teolog-teolog seperti John Nelson Darby, Samuel P. Tregelles dan Charles Henry Mackintosh. Mereka kemudian menerbitkan beberapa karyakarya eksposisional yang memengaruhi tokoh-tokoh kekristenan di Amerika seperti D.L. Moody, James H. Brookes dan C.I. Scorfield. Akan tetapi, tokoh-tokoh aliran dispensasionalisme ini berpendapat bahwa ide ajaran ini sudah muncul sejak abad permulaan. Di samping itu, kaum dispensasionalis memakai Ibrani 1:1-2

\footnotetext{
${ }^{8}$ Pretibulation merupakan pandangan yang mengemukakan bahwa gereja sudah diangkat atau tidak ada lagi sebelum masa tribulasi atau masa kesusahan besar.
} 
sebagai dasar konsep pembagian periodeperiode yang terdapat di dalam Alkitab:

"Setelah pada zaman dahulu Allah berulang kali dan dalam pelbagai cara berbicara kepada nenek moyang kita dengan perantaraan nabinabi, maka pada zaman akhir ini Ia telah berbicara kepada kita dengan perantaraan Anak-Nya, yang telah Ia tetapkan sebagai yang berhak menerima segala yang ada. Oleh Dia Allah telah menjadikan alam semesta".

Di lain pihak, nats ini mengindikasikan akan pengajaran Alkitab mengenai konsep progresive revelation yang menjadi salah satu konsep dasar dari dispensasionalisme.

\section{ABAD PERMULAAN}

Justin Martyr (110-165 A.D). Justin dalam karyanya Dialogue with Trypho melihat adanya beberapa perbedaan ekonomi dalam PL. Beliau mengakui bahwa sebelum sunat dan Taurat, seseorang dapat menyenangkan Allah tanpa harus disunat dan melakukan Taurat. Akan tetapi, setelah wahyu Allah kepada Abraham, sunat menjadi suatu keharusan untuk menyenangkan Dia. Tidak hanya itu, setelah pemberian Taurat, bangsa Israel harus melakukan berbagai ritual, tata cara dan hukum yang terdapat di dalamnya. Lebih lanjut beliau mengatakan ${ }^{9}$ :

"Jika seseorang bertanya kepada kamu, mengapa sejak zaman Henokh, Nuh dan anak-anaknya dan lain-lain dari segi penyunatan, mereka tidak disunat atau memelihara hari Sabat. Namun di sisi lain, para pemimpin lainnya secara khusus sejak diberikannya
Taurat, setelah beberapa generasi selanjutnya yang hidup antara zaman Abraham dan Musa, dibenarkan oleh sunat dan upacara-upacara lainnya seperti Sabat, korban dan persembahan ..."

Dengan demikian, Justin Martyr menganut esensi dari dispensasionalisme dalam ajarannya mengenai perbedaan ekonomi di dalam PL.

Irenaeus (130-200 AD). Irenaeus dalam karya tulisnya mengenai empat perjanjian yang diberikan pada umat manusia, secara khusus ia membuat garis pemisah di antara tiga perjanjian di PL dan Injil. Di samping itu, ia juga menyertakan argumentasinya yang terdapat di dalam karyanya yang berjudul Against Heresies. Buku ini mengemukakan:

"... dan Injil merupakan empat bentuk (quadriform) seperti juga jalan yang diikuti oleh Tuhan ini. Untuk alasan inilah terdapat empat prinsip perjanjian (covenants) yang diberikan kepada manusia; pertama: sebelum air bah yang berada di bawah Adam; kedua: setelah air bah yang berada di zaman Nuh; ketiga: tatkala Taurat telah diberikan di masa Musa; keempat merupakan pembaharuan manusia dan segala sesuatu diperhitungkan di dalamnya melalui arti dari Injil, bangkit dan membawa manusia di atas sayapnya masuk ke dalam Kerajaan Sorga.”

Pemisahan ini merupakan ciri khas dari dispensasionalisme, meskipun ia tidak menggunakan istilah dispensasi dalam pernyataannya. Ryrie memperkuat pandangan ini dengan menyatakan ${ }^{10}$ :

${ }^{9}$ Enns, The Moody Handbook of Theology 2, 151.

${ }^{10}$ Ryrie, Dispensationalism Today, 69. 
"Meskipun Irenaeus tidak menyebutkan akan periodeperiode dispensasi pada bagian ini, namun ia sering berbicara mengenai dispensasi-dispensasi Allah dan khususnya tentang dispensasi kekristenan."

Dengan demikian, Irenaeus secara implisit sebenarnya mengemukakan akan adanya dispensasi-dispensasi pada periodeperiode yang berbeda-beda. Akan tetapi, Irenaeus selangkah lebih maju dalam mengemukakan pandangannya daripada Justin Martyr, yaitu dalam hal pembagian ekonomi, yang bukan hanya di dalam PL tetapi juga PB. Clement dari Alexandria (150-220 A.D). Beliau memberikan empat dispensasi, yaitu periode Adam, Nuh dan Abraham dan Musa. ${ }^{11}$ Clement seperti Justin Martyr yang hanya membagi periode dalam masa PL saja.

Augustine (354-430 A.D) Augustine membedakan antara "dispensasi yang terdahulu" yang berkaitan dengan korban yang dipersembahkan dan masa kini yang tidak lagi mempersembahkan korban. Kendati ada perubahan di dalam persembahan korban, Allah tetap tidak berubah.

Di sini Augustine menyadari bahwa orang-orang beribadah kepada Allah dengan cara yang berbeda pada zaman yang berbeda. Dengan demikian, Augustine menyimpulkan bahwa Allah memiliki beberapa cara kerja yang berbeda di dalam dunia ini sebagaimana ia menjalankan rencana-Nya di sepanjang sejarah. ${ }^{12}$ Hal ini merupakan konsep dasar bagi pemikiran dispensasionalisme. Melalui pandanganpandangan bapa-bapa gereja tersebut, Ryrie menyimpulkan:

\footnotetext{
${ }^{11}$ Enns, The Moody Handbook of Theology 2, 152.

${ }^{12}$ Peter, Teologi Perjanjian Versus

Dispensasionalisme, 21.

${ }^{13}$ Ryrie, Dispensationalism Today, 70.
}

Hal ini tidak mengindikasikan bahwa bapa-bapa gereja pada abad permulaan ini merupakan penganut dispensasionalisme dalam pengertian modern dari kata itu. Akan tetapi, benar bahwa beberapa dari pandangan mereka menjelaskan prinsipprinsip penting yang kelak dikembangkan menjadi dispensasionalisme atau konsep awal dari ajaran dispensasional. ${ }^{13}$

\section{PERKEMBANGAN MODERN}

Pierre Poiret (1646-1719). Ia merupakan seorang filsuf dan mistikus dari Perancis. Ia menulis enam jilid teologi sistematik yang berjudul L'O Economie Divine, yang pertama kali diterbitkan di Amsterdam pada tahun 1687. Karya tulis ini kemudian diterjemahkan ke dalam bahasa Inggris dan diterbitkan di London pada tahun 1713.

Di dalam bukunya ini, ia memberikan akan konsep dispensasi atau sistem pemerintahan Allah di sepanjang sejarah umat manusia. Ia menyajikan tujuh skema dispensasionalisme, yang sebagai berikut: ${ }^{14}$

1. Masa bayi - sampai Air Bah.

2. Masa kanak-kanak - sampai Musa.

3. Masa Remaja - sampai para nabi (kira-kira pada masa Salomo).

4. Masa Pemuda - sampai kedatangan Kristus.

5. Masa Dewasa - "beberapa waktu setelah itu" (periode awal ke-Kristenan).

6. Masa Tua - "masa kehancuran manusia" (periode akhir dari keKristenan).

7. Renovasi dari segala sesuatu - Milenium. ${ }^{15}$

\footnotetext{
${ }^{14}$ Enns, The Moody Handbook of Theology 2, 152153.

${ }^{15}$ Di sini, Poiret mengakui akan adanya perbedaan puncak dari dispensasi secara harafiah dalam periode seribu tahun.
} 
Ehlert menyimpulkan akan pandangan Poiret, secara khusus mengenai skema dispensasi yang ketujuh sebagai berikut:

"Tidak perlu dipertanyakan bahwa kita di sini memiliki susunan dispensasional.

Poiret menggunakan frase "periode atau dispensasi" dan dispensasi ketujuhnya merupakan kerajaan seribu tahun secara harafiah, yakni pada waktu Kristus datang kembali yang kedua kalinya dan memerintah dunia bersama orang-orang kudusNya. Di sinilah Israel akan bertobat dan ikut serta dalam pemerintahan selama seribu tahun ini ...."

Perkembangan modern lebih terperinci pembagian periodenya dibandingkan dengan abad permulaan. Apabila diperhatikan, maka Poiret sebenarnya membagi ke 3 periode besar, yaitu masa PL, PB dan Millenium. Berbeda dengan abad permulaan yang hanya memfokuskan pandangannya pada masa PL saja. John Edwards (1637-1716). Ia pada tahun 1699 menerbitkan dua volume yang Berjudul $A$ Compleat History or Survey of All the Dispensations. Di dalam bukunya ini, ia berusaha untuk memperlihatkan bagaimana pemeliharaan Allah sejak penciptaan sampai pada akhir zaman. Ia memberikan garis besar dispensasi sebagai berikut: ${ }^{17}$

1. Ketidak-berdosaan dan Kebahagiaan Adam. ${ }^{18}$

2. Dosa dan Kesengsaraan. ${ }^{19}$

3. Rekonsiliasi. ${ }^{20}$

A. Ekonomi Patriakh.

\footnotetext{
${ }^{16}$ Ryrie, Dispensationalism Today, 71-72.

${ }^{17}$ Enns, The Moody Handbook of Theology 2, 153.

${ }^{18} \mathrm{Di}$ sini mengemukakan bahwa Adam diciptakan sebagai orang yang tidak berdosa dan orang benar. ${ }^{19} \mathrm{Hal}$ ini terdapat di dalam Kejadian 3 di mana seluruh ciptaan juga ikut terkena hukuman akibat dosa yang dilakukan oleh Adam.
}
a. Periode Adam
b. Periode Nuh.
c. Periode Abraham.
B. Ekonomi Periode Musa.
C. Ekonomi Non-Yahudi.
D. Ekonomi Kristen.
a. Masa bayi, yaitu periode (primitif) yang telah lalu.
b. Masa kanak-kanak, periode sekarang.
c. Masa dewasa, periode (millenium) yang akan datang. ${ }^{21}$
d. Masa tua, periode penutup (kekalahan Iblis dan kemudian dilemparkan ke dalam lautan api).

Garis besar Edwards lebih sistematis dan terperinci dibandingkan dengan Poiret. Edwards bahkan menambahkan akan periode penutup yang merupakan kekalahan Iblis dan penghukumannya yang kekal. Isaac Watts (1674-1748).

Ia merupakan penulis lagu-lagu himne yang terkenal dan juga seorang teolog. Ia berpandangan bahwa dispensasi sebagai masa kondisional di mana Allah memiliki pengharapan tertentu dari manusia dan membuat perjanjian bersyarat dan larangan untuk mereka. Watts menyakini bahwa dispensasi publik dari Allah (bagi manusia) merupakan konstitusi yang bijak dan kudus dari kehendak dan pemerintahanNya yang dinyatakan atau dimanifestasikan kepada mereka (yang berada di dalam urutan periode yang berbeda di dalam sejarah) di mana isinya merupakan tugastugas yang diberikan kepada manusia. Berkat akan diperoleh apabila mereka taat. Hukuman akan diberikan apabila mereka

\footnotetext{
${ }^{20}$ Keadaan di mana Adam dipulihkan, yaitu dari penebusan Adam sampai pada akhir zaman.

${ }^{21}$ Pada periode millennium, tampak bahwa Edwards memahaminya sebagai pemerintahan rohani. Hal ini dikemukakan olehnya, "Mungkin Yesus menampakkan diri secara personal, walaupun Ia tidak akan memerintah secara personal di dunia".
} 
melakukan dosa-dosa yang Allah telah larang. Secara ringkas, dispensasi Allah merupakan peraturan moral yang ditetapkan oleh Allah tatkala berhubungan dengan manusia sebagai makhluk berakal budi. Oleh karena itu, manusia dituntut bertanggung jawab kepada Allah segala tingkah laku mereka baik pada dunia ini maupun dunia yang akan datang. ${ }^{22}$

Garis besar dispensasional dari Watts ialah:

1. Dispensasi dari Ketidak-berdosaan (sebelum kejatuhan).

2. Dispensasi Masa Adam dari Kovenan Anugerah (setelah kejatuhan).

3. Dispensasi Masa Nuh.

4. Dispensasi Masa Abraham.

5. Dispensasi Masa Musa (agama Yahudi).

6. Dispensasi Kristen.

Apabila diperhatikan, maka pembagian dispensasi yang dilakukan oleh Watts tidak jauh berbeda dengan tokohtokoh sebelumnya. Akan tetapi, Watts tidak mencantumkan milenium. Tampaknya ia tidak menganggapnya sebagai dispensasi.

John Nelson Darby (1800-1882). Ia merupakan seorang pemimpin di gereja Plymouth Brethern pada abad 19. Darby merupakan penganut classical dispensationalism. ${ }^{23}$ Melalui pelayanannya, banyak orang Roma Katolik menjadi Protestan. Di samping itu, ia merupakan penulis yang handal. Ia menulis buku sebanyak 40 jilid. Masing-masing jilid terdiri dari enam ratus lembar. Di dalam buku-bukunya ini, Darby menuangkan pengetahuannya dalam bahasa asli Alkitab, filsafat dan sejarah gereja. Ia memberikan pandangannya akan sistem dispensasi yang diyakininya ${ }^{24}$ :

${ }^{22}$ Ryrie, Dispensationalism Today, 73.

${ }^{23}$ Classical dispensationalism merupakan aliran dispensasi yang berdasarkan pada pandanganpandangan dispensasionalis Inggris. Di samping itu, dispensasi ini mendasarkan banyak pandangannya pada Scofield Reference Bible, yang dikarang oleh C.I. Scofield.
1. Tahap Firdaus hingga Air Bah.

2. Nuh.

3. Abraham.

4. Israel.
A. Di bawah Hukum.
B. Di bawah Keimaman.
C. Di bawah Raja-Raja.

5. Non-Israel.

6. Roh Kudus.

7. Milenium.

Hal yang menarik dari pandangan dispensasinya ialah Darby dengan lebih mendalam menjelaskan bahwa di dalam setiap dispensasi, manusia ditempatkan di dalam suatu kondisi di mana manusia memiliki tanggung jawab di hadapan Allah. Di samping itu, Darby dengan tegas mengemukakan bahwa setiap dispensasi berakhir dengan kegagalan. ${ }^{25}$ Ia pun membedakan antara Israel dengan gereja sebagai dua umat Allah yang berbeda. ${ }^{26}$

C. I Scofield (1843-1921). Ia dipengaruhi oleh gerakan Brethen di Amerika telah menghasilkan GerakanGerakan Konferensi Alkitab (Bible Conference Movement) yang dimulai dengan Niagara Bible Conference. Tahun 1870. Pada tahun 1879, ia menghabiskan waktunya untuk menyelidiki dan mendalami Alkitab dan aktif melayani di dalam pelayanan gerejawi. Pada tahun 1909, C. I Scofield menerbitkan bukunya yang terkenal yakni Scofield Reference Bible yang mempromosikan pengajaranpengajarannya kepada khalayak umum. Buku ini kemudian direvisi kembali pada tahun 1917. Sebelum tahun 1930, penjualan dari dua edisi ini sudah mencapai satu juta eksemplar. Ia banyak mempengaruhi banyak orang semasa hidupnya, di antaranya James M. Gray (1851-1935) yang menjadi kepala dari Moody Bible Institute

\footnotetext{
${ }^{24}$ Ryrie, Dispensationalism Today, 75.

${ }^{25}$ Enns, The Moody Handbook of Theology 2, 155.

${ }^{26}$ Clarence B. Bass, Backgrounds to

Dispensationalism (Grand Rapids: Eerdmans, 1960), 64.
} 
dan Lewis Sperry Chafer yang merupakan pendiri dari dari Evangelical Theological College yang kini telah berubah nama menjadi Dallas Theological Seminary. Seminari ini kemudian menyebarkan ajaran dispensasionalisme di antara gereja-gereja seluruh dunia. ${ }^{27}$

Dalam karyanya, ia menunjukkan tujuh dispensasi di mana periode-periode tersebut ditandai di dalam Kitab Suci dengan beberapa perubahan dari cara Allah dalam kaitannya dengan umat manusia. Dispensasi Scofield berbicara mengenai dosa dan tanggung jawab manusia di mana masingmasing dari dispensasi itu diakhiri dengan penghukuman karena adanya kegagalan diakhir setiap dispensasi. Scofield mengategorikan dispensasinya sebagai berikut: 28

1. Ketidak-bersalahan Manusia (dari penciptaan sampai pengusiran dari Eden).

2. Manusia di Bawah Hati Nurani (dari Eden sampai Air Bah).

3. Manusia berkuasa atas Bumi (Nuh sampai Abraham).

4. Manusia di Bawah Janji (Abraham sampai Musa).

5. Manusia di Bawah Hukum (Musa sampai Kristus).

6. Manusia di Bawah Anugerah (kematian Kristus sampai pengangkatan).

7. Manusia di Bawah Pemerintahan Kristus (masa pemerintahan milenium Kristus).

L.W Chafer (1871-1952). Beliau lahir pada tanggal 27 Februari 1871 di Rock Creek, Ohio. Ia merupakan pendiri dan presiden pertama dari Dallas Theological Seminary. Pada masa hidupnya, Chafer

${ }^{27}$ Dallas Theological Seminary juga telah melahirkan tokoh-tokoh yang terkenal seperti John Walvoord, Charles C. Ryrie dan J. Dwight Pentecost.

${ }^{28}$ Enns, The Moody Handbook of Theology 2, 155. telah menulis buku Systematic Theology yang telah memberikan ajaran dispensasi secara komprehensif. Ia memsistematiskan dispensasinya sebagai berikut ${ }^{29}$ :

1. Ketidak-Bersalahan Manusia.

2. Manusia di Bawah Hati Nurani.

3. Pemerintahan Manusia.

4. Janji.

5. Taurat.

6. Anugerah.

7. Pemerintahan Kristus.

Chafer mengambil gagasan yang pernah dicetuskan oleh Scofield sehingga gagasan dispensasinya tidak berbeda sama sekali. John F. Walvoord (1910). Ia pernah menjabat sebagai presiden dari Dallas Theological Seminary, menggantikan L.S Chafer. Ia dengan jelas mengemukakan akan pandangannya yang dispensasi berkenaan dengan eskatologi. Hal ini terdapat di dalam salah satu bukunya di mana ia mengatakan mengenai Israel ${ }^{30}$ :

"1. Hal ini merupakan peristiwa yang nyata bahwa Israel tidak memiliki Tanah Perjanjian secara permanen.

2. Nabi-Nabi dengan jelas menyampaikan janji Allah bahwa Israel akan dikumpulkan kembali dari penyebaran-penyebaran mereka dan akan menetapi Tanah Perjanjian selama kerajaan milenium.

3. Ini merupakan bukti bahwa janji yang diberikan kepada Israel tidak akan dipenuhi oleh gereja ataupun orang-orang non-Yahudi.

4. Jadi, janji tersebut harus dipenuhi oleh benih secara fisik dari Yakub untuk menjaga perjanjian Abraham".

\footnotetext{
${ }^{29}$ Lewis Sperry Chafer, Systematic Theology (Texas: Dallas Seminary Press, 1947), 46.

${ }^{30}$ John F. Walvoord, Major Bible Prophecies (Grand Rapids: Zondervan, 1991), 95.
} 
Dengan demikian, nampak jelas bahwa Walvoord membedakan antara Israel dengan gereja. Ada janji-janji yang tidak dapat dinikmati oleh gereja tetapi sematamata hanya untuk Israel. Secara khusus, janji mengenai tanah. Hal ini diyakini Walvoord akan dipenuhi dalam kerajaan seribu tahun. Oleh karena itu, kerajaan seribu tahun tersebut tidak dapat ditafsirkan secara alegoris tetapi secara harafiah. Sistem hermeneutika yang dipakai.

Hermeneutika merupakan ilmu dan seni menafsirkan Alkitab. Ilmu karena hermeneutik berkaitan dengan prinsipprinsip di dalam suatu sistem yang teratur. Ilmu ini dimaksudkan untuk memperoleh dan menggolongkan prinsip-prinsip yang diperlukan untuk menafsirkan Kitab Suci secara tepat. Seni karena berkaitan dengan perihal-perihal untuk menerapkan prinsipprinsip yang telah diperoleh. ${ }^{31}$ Melalui prinsip-prinsip hermeneutika, akan membawa penafsir ke dalam suatu sistem teologi. Dengan kata lain, sistem teologi yang berbeda dari Teologi Perjanjian dengan Dispensasionalisme merupakan perbedaan sistem hermeneutika.

Bernard Ramm mengatakan bahwa prinsip penafsiran Dispensasionalisme merupakan penafsiran yang literal. Hal ini berarti bahwa setiap kata memiliki arti yang sama dalam penggunaannya baik dalam tulisan, pengucapan ataupun pemikiran. ${ }^{32}$ Di samping itu, prinsip penafsiran literal juga harus didukung dari grammatikal historikal. Cara ini digunakan bertujuan untuk menentukan penggunaan yan lazim dan biasa dari bahasa maka berbagai peraturan tata bahasa dan retorika harus diperhatikan. Tidak hanya itu, pelbagai aspek kultural dan historis dari Alkitab pun harus dipertimbangkan juga. Hal ini sering kali disebut sebagai normal interpretation atau plain interpretation yang berarti

\footnotetext{
${ }^{31}$ Kevin J. Conner \& Ken Malmin, Interpreting The Scriptures (Malang: Gandum Mas, 2004), 1.

${ }^{32}$ Barnard Ramm, Protestant Biblical

Interpretation (Boston: W. A wilde, 1956), 89-92.
}

interpretasi untuk mencari arti yang biasa atau sederhana.

Dengan demikian, Dispensasionalis menerapkan metode penafsiran literal secaa konsisten termasuk di dalam studi eskatologis. Enns mengatakan bahwa banyak orang-orang non-Dispensasionalis yang konservatif menafsirkan Alkitab secara literal kecuali nubuatan. ${ }^{33}$ Penafsiran literal tidak mengesampingkan bahwa di dalam Alkitab juga banyak terdapat arti kiasan.

Kitab Mazmur menjadi salah satu bagian Alkitab yang memiliki banyak katakata bernuansa kiasan. Banyak penafsir yang keliru memakai istilah kiasan sebagai lawan dari literal. Hal ini menimbulkan kesan bahwa arti kiasan dari kata-kata berlawan dengan arti secara literal. Oleh karena bahasa kiasan merupakan bagian dari komunikasi yang lazim, maka bahasa kiasan juga mencakup dalam sistem penafsiran literal. Dengan kata lain, penafsiran literal meliputi juga yang bersifat kiasan. ${ }^{34}$

Jadi, kaum dispensasionalis menerima interpretasi figuratif, simbolik dan spiritual apabila Alkitab itu sendiri yang menyatakan demikian. Dalam menafsirkan peristiwa eskatologi, kaum dispensasionalis mendasarkan penafsiran literal nubuatannya pada waktu kedatangan Kristus yang pertama kalinya. Hal ini merupakan alasan yang kuat bagi kalangan dispensasionalis untuk mengharapkan penggenapan nubuatan berkaitan dengan kedatangan Kristus yang kedua kali secara literal pula.

Ryrie memberikan argumentasiargumentasinya mengenai alasan kaum dispensasionalis memakai prinsip hermeneutika secara literal ${ }^{35}$ :

1. Hal ini dapat diterima secara filosofikal. Tujuan bahasa adalah menuntut interpretasi literal. Bahasa

\footnotetext{
${ }^{33}$ Enns, The Moody Handbook of Theology 2, 160.

${ }^{34}$ Conner, Interpreting The Scriptures, 33.

${ }^{35}$ Ryrie, Dispensationalism Today, 86-89.
} 
diberikan Allah supaya dapat berkomunikasi dengan manusia. Jika Allah merupakan pencipta bahasa dan jika tujuan utama dari penciptaan bahasa ialah untuk menyalurkan Firman-Nya kepada manusia. Di samping itu, Allah yang penuh dengan kasih dan hikmat akan memakai bahasa yang diberikan-Nya kepada manusia yaitu bahasa yang dapat dipahamai oleh semua kalangan manusia. Dengan demikian, penafsiran Alkitab menuntut bahasa literal, normal dan biasa yang harus Allah pakai dalam menyampaikan Firman-Nya kepada manusia.

2. Dispensasionalis memegang prinsip literal karena penafsiran inilah satusatunya yang paling Alkitabiah. Nubuatan PL mengenai Yesus baik dalam kelahiran, kehidupan, kematian dan kebangkitan-Nya semuanya digenapi secara literal. Oleh karena itu, Alkitab jelas harus ditafsirkan secara literal.

3. Prinsip penafsiran literal merupakan hal yang paling logis. Jika penafsir tidak menggunakan penafsiran literal dalam Alkitab maka semua objektifitas dari isi Alkitab menjadi hilang. Apabila penafsir tidak menggunakan tafsiran ini, maka orang akan dapat menemukan banyak arti dan bahkan dapat bertentangan maknanya di dalam satu nats. Oleh karena itu, literal merupakan tafsiran yang logis dan rasional.

Akan tetapi, penafsiran literal tidak semata-mata milik kaum dispensasionalis. Beberapa kaum konservatif pun juga menggunakan metode penafsiran ini. Akan tetapi yang menjadi perbedaannya ialah, kaum dispensasionalis menggunakan penafsiran literal secara konsisten di dalam semua studi Alkitab. Bagi nondispensasionalis menggunakan prinsip alegoris atau menspiritualkan makna Alkitab bila bertemu dengan bagian-bagian yang bersifat nubuatan.

Pandangan eskatologi dari Dispensasionalisme. Dispensasionalisme (dan premilenialisme historis) menyakini bahwa Kristus akan memerintah di bumi selama seribu tahun sesudah Ia datang kembali.

Di samping itu, kaum dispensasionalis memberikan perbedaan yang mendasar dan kekal antara Israel dan gereja.

Orang-orang dispensasionalis percaya bahwa di sepanjang sejarah, Allah sedang menggenapi dua macam rencana-Nya: yang satu berkaitan dengan bumi, dengan melibatkan umat di bumi dan sasaransasaran duniawi, yaitu Yudaisme; yang lainnya berkaitan dengan sorga dengan melibatkan umat sorgawi dan sasaransasaran sorgawi yaitu keKristenan. ${ }^{36}$

Walvoord mengemukakan bahwa hal yang paling penting dalam penafsiran premilenialisme adalah bahwa Alkitab, khususnya Perjanjian Baru, membedakan antara tujuan yang Allah tetapkan bagi gereja dan bagi bangsa Israel. Orang-orang keturunan Yakub pada masa sekarang ini memiliki hak istimewa yang sama seperti bangsa-bangsa lain dalam hal iman kepada Kristus dan sebagai bagian dari tubuh Kristus.

Meskipun demikian, baik PL maupun PB menyatakan bahwa bangsa Israel hanya akan memperoleh janji di dalam Kristus di masa yang akan datang, ketika Kristus memerintah langsung atas mereka. Pada masa sekarang ini merupakan waktu penggenapan bagi rencana dan tujuan Allah untuk memanggil sebagian dari orang-orang Yahudi dan non-Yahudi untuk percaya kepada Kristus dan hidup sebagai umat yang kudus. Bilamana tujuan ini

${ }^{36}$ Lewis Sperry Chafer, Dispensationalism (Dallas: Seminary Press, 1936), 107. 
tercapai, maka Allah akan melaksanakan penghakiman-Nya yang menakutkan sebagai pendahuluan bagi kerajaan milenium yang akan dipimpin oleh Kristus. Setelah itu, Allah akan menegakkan kebenaran dan damai sebagai karakteristik utama kerajaan seribu tahun. ${ }^{37}$

Kaum dispensasionalis merujuk kepada Perjanjian Lama di mana terdapat banyak janji bahwa suatu saat di masa yang akan datang, Allah akan menegakkan Kerajaan-Nya di bumi yang akan melibatkan orang-orang Israel, yaitu bangsa perjanjian Allah sejak semula. Dalam perjanjian Allah dengan Daud, Allah berjanji bahwa salah seorang dari keturunan Daud (yaitu, Mesias yang akan datang) akan duduk di takhta Daud selama-lamanya dan memerintah atas bangsa Israel. Janji Allah yang baru sebagaimana yang tertulis dalam Yeremia 31:31-34, meskipun mencakup beberapa hal yang telah digenapi dalam diri orang-orang percaya pada masa sekarang ini adalah untuk bangsa Israel yang hanya akan digenapi dalam milenium yang akan datang. Ayat-ayat lainnya dalam Mazmur dan nabi-nabi ${ }^{38}$ menubuatkan bahwa di masa yang akan datang bangsa Israel akan sekali lagi dikumpulkan di tanah Kanaan dan akan menikmati masa yang penuh kemakmuran dan berkat serta akan memperoleh status yang lebih istimewa dibandingkan bangsa-bangsa lainnya. Pada masa itu, mereka akan hidup di bawah pemerintahan yang penuh kasih karunia dan sempurna dari Sang Mesias yang merupakan keturunan Daud. Kalangan dispensasionalis kemudian menyimpulkan

\footnotetext{
${ }^{37}$ John F. Walvoord, The Millennial Kingdom (Findlay Ohio: Dunham, 1958), vii-viii.

${ }^{38}$ Mzm. 72:1-20; Yes. 2:1-4; 11:1-9; 11-16; 65:1825; Yer. 23:5-6; Am. 9;11-15; Mik. 4:1-4; Zak. $14: 1-9 ; 16-21)$.

${ }^{39}$ Kata 'diangkat' ditulis sebagai kata kerja masa depan yang pasif dari harpazo. Sebuah kata yang digunakan untuk menggambarkan perampokperampok yang merenggut barang rampasan mereka, burung rajawali yang merenggut mangsanya. Di dalam PB, Paulus yang diangkat
}

bahwa semua ini akan terjadi pada pemerintahan seribu tahun.

Kedatangan Yesus Kristus akan terjadi di dalam dua fase. Fase pertama merupakan pengangkatan (rapture) yang dapat terjadi setiap saat, tiba-tiba dan tanpat peringatan sebelumnya. Yesus akan mengangkat mereka yang siap sedia bagi kedatangan-Nya. Pada pengangkatan tersebut, Kristus belum sepenuhnya turun ke bumi, Ia masih berada di awan-awan (1 Tes. 4:16-18; II Tes. 2:1). Sebelum pengangkatan, terjadilah kebangkitan seluruh orang-orang percaya, khususnya orang-orang kudus dari masa Perjanjian Lama. Orang-orang percaya yang masih hidup, baik orang Yahudi maupun bangsa lain, akan dalam sekejap mata diubahkan dan dimuliakan. Baik orang percaya yang dibangkitkan maupun diubahkan akan diangkat ke awan-awan untuk bertemu dengan Tuhan Yesus di langit. ${ }^{39}$ Bersamasama dengan Kristus, seluruh orang percaya yaitu Gereja akan naik ke Sorga untuk merayakan perjamuan pernikahan dengan Anak Domba selama tujuh tahun. ${ }^{40}$

Tujuh tahun yang dimaksud di atas merupakan penggenapan dari minggu ketujuh puluh dari nubuat Daniel (Dan. 9:24-27). Kaum dispensasionalis percaya bahwa meskipun enam puluh sembilan minggu yang disebutkan dalam nubuat tersebut telah digenapi pada saat kedatangan Kristus yang pertama, namun nubuat tentang minggu ketujuh puluh (ay. 27) hanya akan digenapi sesudah terjadinya pengangkatan. Selama tujuh tahun ini, yaitu ketika Gereja berada di Sorga, sejumlah peristiwa tetap berlangsung di bumi ${ }^{41}$ :

\footnotetext{
dengan kuasa besar ke tingkat ketiga dari Surga (II Kor. 12:2). Bahasa Latin menerjemahkan kata ini raptus yang merupakan akar kata rapture dalam bahasa Inggris. Jadi, “dibawa pergi” dapat diterjemahkan "diangkat" dan kata "pengangkatan" menjadi istilah yang resmi untuk menunjuk kepada peristiwa ini yang telah dinubuatkan oleh Alkitab. ${ }^{40}$ William W. Menzies \& Stanley M. Horton, Doktrin Alkitab (Malang: Gandum Mas, 1998), 219 ${ }^{41}$ Chris Marantika, Eskatologi (Yogyakarta: Iman Press, 2004), 79.
} 
1. Digenapinya akan masa kesusahan sebagaimana yang dinubuatkan dalam Dan. 9:27, yaitu pertengahan tujuh masa yang disebut kesusahan besar.

2. Antikristus mulai melaksanakan pemerintahannya yang penuh kejahatan. Sebuah pemerintahan yang akan mencapai klimaksnya ketika pribadi antikristus tersebut ingin disembah sebagai Allah.

3. Penghakiman yang menakutkan, jatuh ke atas orang-orang yang masih tinggal di bumi.

4. Pada masa ini, sisa-sisa Israel akan berbalik kepada Yesus dan mengakui-Nya sebagai Mesias, yaitu 144.000 orang Israel yang telah dimeteraikan seperti yang tertulis dalam Wahyu 7:3-8.

5. Sisa-sisa Israel ini akan mulai memberitakan "Injil Kerajaan" yaitu Injil yang inti beritanya adalah ditegakkannya kembali kerajaan Daud. Di samping itu, termasuk pula berita tentang salib dan perlunya orang untuk bertobat dan beriman.

6. Melalui kesaksian sisa-sisa orang Yahudi inilah, sejumlah besar bangsa-bangsa lain akan dibawa ke dalam keselamatan (Why. 7:9);

7. Raja-raja fasik di bumi beserta tentara dan nabi-nabi palsunya akan bersatu dan menyerang umat Allah dalam Perang Harmageddon.

Di akhir masa tujuh tahun tersebut, Kristus akan turun kembali dalam kemuliaan beserta dengan Gereja-Nya. Ia akan turun sampai ke bumi dan membinasakan musuh-musuh-Nya dan mengakhiri perang Harmagedon. Pada waktu itulah bangsa Israel akan dikumpulkan kembali di tanah Palestina.

\footnotetext{
${ }^{42}$ Ryrie, Dispensationalism Today, 146.

${ }^{43}$ Ada mereka yang dilahirkan pada masa ini akan menjadi orang perccaya sejati. Akan tetapi, ada pula yang memberontak kepada Tuhan di dalam masa ini. Orang-orang yang memberontak akan langsung dibinasakan oleh Tuhan. Oleh karena itu, orang-
}

Sejumlah besar orang Israel yang masih hidup ketika Kristus turun ke bumi akan beriman kepada Kristus dan diselamatkan. Hal ini seperti yang telah dinubuatkan dalam Perjanjian Lama dan Perjanjian Baru. Iblis akan diikat, dilemparkan ke dalam jurang maut dan dimeteraikan selama seribu tahun, yaitu suatu periode waktu dalam arti secara harafiah.

Setelah semuanya ini, maka kerajaan seribu tahun akan dimulai yang dipimpin oleh Yesus itu sendiri. Ia akan duduk di takhta yang berada di Yerusalem dan memerintah atas bangsa-bangsa Yahudi serta non-Yahudi. Di awal kerajaan ini tidak ada orang jahat yang tinggal di bumi. Pemerintahan ini merupakan penggenapan dari janji Allah pada masa Perjanjian Lama. Ryrie mengatakan bahwa tujuan pemerintahan di bumi atas orang-orang Israel, sebagaimana diajarkan oleh dispensasionalisme adalah menyangkut janji kepada Israel sebagai bangsa, yang akan digenapi pada masa seribu tahun yaitu ketika mereka hidup di bumi dengan belum mengenakan tubuh kebangkitan. Kerajaan seribu tahun bagi Israel sama sekali tidak berbicara tentang orang-orang Israel yang telah mati sebelum kerajaan tersebut digenapi. ${ }^{42}$ Mereka yang masuk ke dalam kerajaan seribu tahun akan tetap menikah dan memiliki anak. ${ }^{43}$ Di samping itu, ini merupakan masa yang penuh kemakmuran, produktivitas dan damai sejahtera (Yes. 2:4). Dengan kata lain, masa yang belum pernah ada di bumi sebelumnya. Bumi akan dipenuhi oleh pengenalan akan Allah. Kemuliaan Allah akan tinggal pada baitNya yang sudah dibangun kembali (Yes. 45:23; Za. 8:23; 9:7; 13:2; 14:6, Mal. 11:1; Why. 5:9-14). Sukacita meliputi seluruh bumi. ${ }^{44}$ Tidak hanya itu saja, bumi akan menjadi subur dan sangat produktif (Yes.

orang yang mati di dalam usia 100 tahun akan dianggap muda dan bila tidak mencapai usia 100 tahun akan dianggap kena kutuk (Yes. 65:20). ${ }^{44}$ Orang-orang yang dibebaskan Tuhan akan pulang dan masuk ke Sion dengan bersorak-sorai sedang sukacita abadi meliputi mereka; kegirangan dan 
35:1-7). Penuaian yang terjadi terusmenerus (Am. 9:14). Kehadiran Allah di bumi akan dirasakan secara luar biasa (Za. 2:2; 10:13; Why. 21:3). ${ }^{45}$

Di samping itu, orang-orang percaya yang telah dibangkitkan akan ikut memerintah di dalam kerajaan seribu tahun. Namun, mereka hidup di dalam Yerusalem baru yang bersifat sorgawi sebagaimana digambarkan dalam Wahyu 21:1-22:5. Selama masa seribu tahun, Yerusalem sorgawi tersebut akan berada di awan-awan, di atas bumi dan memancarkan terangnya ke seluruh bumi. Akan tetapi, orang-orang percaya yang dibangkitkan dapat turun dari Yerusalem baru ke bumi dan terlibat dalam pemerintahan. ${ }^{46}$

Setelah pemerintahan seribu tahun, Iblis akan dilepaskan. Pembebasan Iblis ini memperlihatkan bahwa setelah dunia menyaksikan damai dan berkat selama seribu tahun di bawah pemerintahan Kristus, masih ada orang-orang yang mengikut Iblis. Hal ini kemudian berakhir dengan dibakarnya Iblis dan pengikutpengikutnya dengan api dari Sorga. Iblis sendiri akan dilemparkan ke dalam lautan api selamanya. Setelah itu akan ada penghakiman bagi orang fasik dan kematian yang kedua di dalam lautan api. ${ }^{47}$

Pada akhirnya seluruh orang percaya akan masuk ke dalam kehidupan kekal. Allah menciptakan langit dan bumi yang baru di mana dosa dan kelemahan akan dihapuskan. Yerusalem sorgawi akan turun ke bumi yang baru. Di sanalah Allah dan seluruh umat-Nya akan tinggal bersama dalam kemuliaan yang sempurna selamalamanya. Dengan demikian, Perjanjian Lama memberikan sebuah pengharapan bagi seluruh bangsa Israel yang penggenapannya akan sepenuhnya terwujud pada masa kerajaan seribu tahun. Pengharapan orang-orang percaya dalam

sukacita akan memenuhi mereka, kedukaan dan keluh kesah akan menjauh. (Yes. 35:10, 51:11; 55:12; 61:10; Yer. 31:12).

${ }^{45}$ Marantika, Eskatologi, 151-152.

${ }^{46}$ Walvoord, The Millennial Kingdom, 39.
PL bagi adanya sebuah kota yang kekal akan diwujudkan melalui kebangkitan yang terjadi di dalam Yerusalem sorgawi, di mana Israel - tanpa kehilangan identitasnya - akan bergabung bersama-sama dengan seluruh umat Allah lainnya yang telah dibangkitkan dan diubahkan untuk mengambil bagian dalam kemuliaan Kristus selama-lamanya. ${ }^{48}$ Kelemahan-kelemahan eskatologi Dispensasionalisme menurut Teologi Perjanjian. Keberatan tentang pembedaan antara Israel dengan gereja.

Hoekema berpendapat bahwa premilenialisme dispensasi mengabaikan hal yang sangat mendasar dalam Alkitab, yaitu kesatuan Alkitab. ${ }^{49}$ Kaum dispensasionalis membagi sejarah dunia ke dalam beberapa periode. Bahaya yang ditimbulkan ialah tampaknya kaum ini lebih menekankan akan perbedaan-perbedaan di antara periode sejarah penebusan ketimbang kesatuan sejarah penebusan yang merupakan sifat dasar bagi sejarah tersebut. Lebih jauh lagi, ada beberapa hal lainnya yang perlu diperhatikan. Tatkala seseorang mengabaikan kesatuan sejarah penebusan dan membuat berbagai perbedaan di antara periode dispensasi yang berbeda-beda, maka bahaya yang ditimbulkan ialah tidak mampunya untuk mengenali perkembangan yang bersifat kumulatif dan permanen yang menandai hubungan Allah dengan umatNya pada masa Perjanjian Baru. Alkitab dengan jelas menyebutkan bahwa Kristus telah menghancurkan tembok pemisah antara orang Yahudi dengan bangsa lain (ef. 2:14-15). Berdasarkan pemahaman ini, mengapa kaum dispensasionalis masih terus menerus menekankan pemisahan antara bangsa Yahudi dan bangsa-bangsa lain di masa seribu tahun? Dengan mengatakan bahwa orang-orang Yahudi akan menempati posisi khusus dan ditinggikan lebih daripada bangsa-bangsa lain? Kaum

\footnotetext{
${ }^{47}$ Horton, Doktrin Alkitab, 253.

48 J. Dwight Pentecost, Things to Come (Findlay, Ohio: Dunham, 1958), 546.

${ }^{49}$ Anthony A. Hoekema, Alkitab dan Akhir Zaman (Surabaya: Momentum, 2004), 263.
} 
dispensasionalis tampaknya menganggap bahwa tembok pemisah antara bangsa Yahudi dan bangsa-bangsa lain telah diruntuhkan dalam periode dispensasi zaman gereja sekarang ini. Namun seribu tahun merupakan suatu periode dispensasi di mana mereka telah mengabaikan apa yang PB katakan penghapusan tembok baik orang Yahudi maupun non-Yahudi. ${ }^{50}$

Keberatan kedua ialah

dispensasionalisme melupakan bahwa menurut Perjanjian Baru, gereja merupakan "Israel baru" (Rm. 9:6; Gal. 6:15-16), "Yahudi" (Rm. 2:28-29), "keturunan Abraham" (Gal. 3:29) ${ }^{51}$, "Sion" (1 Pet. 2;6; Ibr. 12:22). Mereka yang dicuci dengan darah Kristus telah menjadi "dua belas suku" yang baru (Yak. 1:1), "orang-orang pendatang yang tersebar" di antara bangsa-

\footnotetext{
${ }^{50}$ Anthony A. Hoekema, Alkitab dan Akhir Zaman, 266.

${ }^{51}$ Bagian ini dengan jelas menyatakan bahwa seluruh orang percaya dalam PB merupakan keturunan Abraham., bukan dalam arti fisik tetapi rohani. Conn melihat bahwa gereja PB diidentikan dengan Israel sejati dan seluruh anggota di dalamnya merupakan pewaris sejati dari janji yang Allah buat dengan Abraham.

${ }^{52}$ Harvie M. Conn, Teologia Kontemporer (Malang: SAAT, 1996), 132.

${ }^{53}$ Paulus dengan jelas menyatakan dalam Gal. 6:1516, "Sebab bersunat atau tidak bersunat tidak ada artinya, tetapi menjadi ciptaan baru, itulah yang ada artinya. Dan semua orang, yang memberi dirinya dipimpin oleh patokan ini, turunlah krinya damai sejahtera dan rahmat atas mereka dan atas Israel milik Allah". Dalam bahasa aslinya adalah kai epi ton Israel tou theou. Walvoord mengatakan bahwa kai harus diterjemahkan dan, sehingga "Israel milik Allah" artinya adalah orang-orang Yahudi yang percaya. Akan tetapi, Hoekema membantah hal tersebut. Permasalahan penafsiran semacam ini adalah bahwa orang-orang Yahudi yang percaya itu sudah tercakup dalam kalimat "dan semua orang, yang memberi dirinya dipimpin oleh patokan ini"yaitu, semua orang percaya yang sejati, yang terdiri dari bangsa Yahudi maupun bangsa-bangsa lain. Dengan kata lain, Hoekema berpendapat bahwa Paulus di sini menjelaskan gereja sebagai Israel sejati.

${ }^{54}$ Untuk memahami Roma 11:25-26a, Hoekema mengajak untuk melihat dengan teliti konteks dari pasal ini. Pasal 9, Paulus menyingkapkan bahwa penolakan Tuhan atas Israel adalah tidak
}

bangsa (1 Pet. 1:1). ${ }^{52}$ Hoekema bahkan dengan tegas mengatakan bahwa ajaran yang mengatakan Allah memiliki tujuan yang berbeda bagi Israel dan gereja merupakan paham yang tidak benar. Pada kenyataannya, PB sendiri sering kali menjelaskan ungkapan-ungkapan yang berkaitan dengan Israel dan diaplikasikan kepada gereja pada masa PB, yang mencakup baik orang-orang Yahudi maupun bangsa-bangsa lain. ${ }^{53}$ Kalangan dispensasionalis sering kali memakai Roma 11 sebagai acuan untuk mengajarkan periode waktu di masa yang akan datang, yang merupakan masa penuh berkat hanya bagi bangsa Israel. Akan tetapi, Hoekema menyakini bahwa Roma 11:26 tidak mengajarkan akan pertobatan bangsa Israel di masa datang. ${ }^{54}$ Nats ini terambil dari

sepenuhnya. "Sebab tidak semua orang yang berasal dari Israel adalah orang Israel" (9:6). Artinya, meskipun benar bahwa banyak di antara orang Israel adalah orang-orang yang terhilang, tetapi Israel sejati akan diselamatkan. Secara ajaib Allah menggenapi janji-Nya atas diri mereka yang merupakan anak-anak perjanjian. Dari sejak permulaan sejarah Israel, telah ada pemisahan di dalam bangsa itu sendiri atas kehendak Tuhan. Rasul Paulus menjelaskan beberapa bentuk pemisahan tersebut yaitu yang berasal dari Ishak akan disebut sebagai keturunan Abraham (9:7); bukan Esau tetapi Yakub yang dipilih sebagai penerus perjanjian $(9: 10: 12)$. Pada pasal 10, Paulus melanjutkan dengan menunjukkan bahwa penolakan atas sebagain orang Israel tidaklah sewenang-wenang. Mereka telah menolak Injil dan beriman kepada Yesus. Rm. 10:12 dituliskan bahwa tidak ada perbedaan bagi orang Yahudi maupun orang Yunani mengenai cara memperoleh keselamatan. Oleh karena itu, Hoekema berpendapat bahwa "jumlah yang penuh" (pleroma) harus dimengerti secara eskatologis, yaitu keseluruhan bangsa-bangsa non-Yahudi yang hendak Allah selamatkan. Ketika seluruh jumlah bangsa-bangsa lain di sini tidak hanya akan terjadi di masa yang akan datang, melainkan terus berlangsung di sepanjang sejarah gereja. Akan tetapi, akan tetap ada orang-orang Israel yang berbalik kepada Tuhan hingga kedatangan kedua di mana pada saat yang bersamaan jumlah yang penuh dari bangsa-bangsa lain yang diselamatkan juga akan terpenuhi. Dengan demikian, Rm, 11 bukan hanya berbicara mengenai pertobatan Yahudi saja tetapi juga non-Yahudi dan terus berlangsung dari 
Yesaya 59:20 dan 27:955, yang sering digunakan oleh kaum dispensasionalis sebagai rujukan kedatangan Kristus yang kedua kali. Hal ini tidaklah tepat apabila dimengerti secara demikian karena kalimat dalam Yesaya ini menggambarkan akan kedatangan Yesus yang pertama telah menghapuskan dosa manusia. ${ }^{56}$ Bahkan jika dua ayat dari Yesaya tersebut hendak dikenakan pada Kedatangan Kedua, tentunya Alkitab pasti akan mencatat dari Sorga (bukan dari Zion) akan datang penebus. Oleh karena itu, pertobatan dari orang Yahudi dan non-Yahudi (yang akan terjadi sepanjang sejarah) akan disebut sebagai israel sejati. ${ }^{57}$

\section{KEBERATAN KERAJAAN 1000 TAHUN}

Perjanjian Lama tidak pernah mengajarkan akan adanya kerajaan seribu tahun yang bersifat fisik. Kaum dispensasionalis menyatakan bahwa PL banyak bukti yang berbicara tentang pemerintahan Kristus selama seribu tahun. Dispensasionalis mendasarkan pemahamannya ini dari Yes. 65:17-25.

kedatangan Kristus yang pertama hingga yang kedua. Lagipula, kalaupun seseorang cenderung memahami perikop tersebut sebagai ajaran tentang pertobatan Israel di masa akan datang, ia masih harus mengakui bahwa Roma 11 sama sekali tidak berbicara mengenai Israel yang dikumpulkan kembali ke tanah Kanaan atau pemerintahan Kristus di masa yang akan datang dalam kerajaan seribu tahun.

${ }^{55}$ Dari Sion akan datang Penebus, Ia akan menyingkirkan segala kefasikan daripada Yakub. Dan inilah perjanjian-Ku dengan mereka, apabila Aku menghapuskan dosa mereka.

${ }^{56}$ George Eldon Ladd, Theology Of the New

Testament (Grand Rapids: Eerdmans, 1974), 562.

${ }^{57}$ Hoekema, Alkitab dan Akhir Zaman, 190-200.

${ }^{58}$ Jelas sekali bahwa ayat 17 berbicara mengenai langit dan bumi yang baru. Ayat 18 mengajak pembaca untuk "bersukacita selama-lamanya" bukan berbicara mengenai kerajaan seribu tahun di dalam langit dan bumi yang baru, yang disebutkan dalam ayat 17. Di sini Yesaya tidak sedang berbicara mengenai sebuah keberadaan baru yang akan berakhir tidak lebih dari seribu tahun melainkan tentang kondisi kekal yang penuh
Semua sepakat (dispensasionalisme dan teologi perjanjian) bahwa ayat 17 berbicara mengenai langit dan bumi baru, namun dispensasional membatasi ayat 18 25 hanya pada milenium yang akan mendahului langit dan bumi baru. Namun, Hoekema berpendapat bahwa seseorang akan mendapati gambaran akan milenium dalam perikop ini, apabila ia mengabaikan isi dalam ayat $17-19 .{ }^{58}$ Akan tetapi, dispensasionalis sering menggunakan ayat $20^{59}$ sebagai argumentasi mereka akan adanya kerajaan seribu tahun. Hoekema mengakui bahwa ayat ini sulit untuk dimengerti, tetapi menyakini bukan mengenai kerajaan seribu tahun. ${ }^{60}$ Pada ayat 20 dikatakan bahwa orang yang tidak mencapai usia seratus tahun akan dianggap kena kutuk. Ayat 22 mendukung akan nats ini, "sebab umur umat-Ku akan sepanjang umur pohon, dan orang-orang pilihan-Ku akan menikmati pekerjaan tangan mereka".

Dengan demikian, nats di atas tidak perlu harus dimengerti sebagai gambaran akan kerajaan seribu tahun, tetapi masuk akal apabila dimengerti sebagai nubuat tentang kondisi dalam bumi yang baru di

kemuliaan. Lebih lanjut dijelaskan dalam ayat 19 merupakan gambaran tambahan bagi kondisi yang dalam Why. 21:4 yang merupakan tanda bagi kondisi kekekalan: "Tidak akan ada lagi perkabungan atau ratap tangis atau dukacita, sebab segala sesuatu yang lama itu telah berlalu". 59 Ayat 20, "Di situ tidak akan ada lagi bayi yang hanya hidup beberapa hari atau orang tua yang tidak mencapai usia suntuk, sebab siapa yang mati pada usia seratus tahun akan dianggap kena kutuk". Oleh karena kematian, disebutkan dalam ayat ini, maka kaum dispensasionalis mengatakan bahwa perikop ini tidak membicarakan langit dan bumi yang baru melainkan zaman milennium.

${ }^{60}$ Berdasarkan ayat 19, Yesaya berkata, "Di dalamnya tidak akan kedengaran lagi bunyi tangisan dan bunyi erangpun tidak". Dapatkah seseorang membayangkan sebuah kematian tanpa tangisan? Yes. 25:8 telah menyatakan bahwa tidak akan ada lagi kematian bagi umat Allah di dalam kondisi kekekalan! Nubuat ini juga mencakup bahwa tidak akan ada lagi air mata: "Ia, Tuhan semesta alam, akan meniadakan maut untuk seterusnya; dan Tuhan Allah akan menghapuskan air mata dari pada segala muka. 
masa yang akan datang. ${ }^{61}$ Di samping itu, Yesaya 11:6-10 sering dianggap sebagai lukisan yang indah dalam kerajaan seribu tahun di mana "serigala dan anak doma akan bersama-sama makan rumput". Hoekema sependapat dengan dispensasionalis bahwa perikop ini tidak sepatutnya dimengerti sebagai gambaran dari sorga. ${ }^{62}$

Kalimat, "sebab seluruh bumi penuh dengan pengenalan bumi akan Tuhan, seperti air laut yang menutupi dasarnya" bukanlah gambaran yang tepat bagi kerajaan seribu tahun berlangsung tetap akan ada sebagian orang yang tidak mengenal atau mencintai Tuhan, yaitu mereka yang akan berkumpul di akhir masa seribut tahun untuk mengadakan peperangan terakhir kepada kemah-kemah orang-orang percaya.

Dengan demikian, ini harus dimengerti sebagai gambaran bumi yang baru bukan kerajaan seribu tahun. Di pihak lain, dispensasional sering kali menggunakan juga Yehezkiel 40-48 yang berjudul "Bait Allah dalam kerajaan seribu tahun dan penyembahan di dalamnya" (40:1-47:12) dan "pembagian tanah selama zaman kerajaan seribu tahun" (42:13$48: 35){ }^{63}$

Dispensasionalis mengatakan bahwa pasal-pasal ini menubuatkan akan pembangunan kembali Bait Allah Yerusalem di masa kerajaan seribu tahun dan ibadah yang akan mengikutinya. Akan tetapi kesulitan terbesar ialah memahami

\footnotetext{
${ }^{61}$ Ayat 25 mendukung argumen ini, "Tidak ada yang akan berbuat jahat atau yang berlaku busuk di segenap gunung-Ku yang kudus".

${ }^{62}$ Hoekema, Alkitab dan Akhir Zaman, 270.

${ }^{63}$ Pasal-pasal ini berisi akan sebuah penglihatan tentang Bait Allah yang akan didirikan kembali ketika bangsa Israel kembali dari pembuangan. Di samping itu, berisi juga penjelasan mengenai Bait Allah dan ukuran-ukuran yang harus diperhatikan di Bait Allah: korban penghapus dosa, korban penebus salah, korban bakaran dan korban pendamaian.

${ }^{64}$ Apakah persembahan korban-korban sembelihan masih diperlukan sesudah Kristus menggenapi semua korban tersebut? Untuk apakah umat Allah di masa milennium harus kembali melaksanakan
}

pasal-pasal di atas secara harafiah adalah adanya korban-korban binatang. ${ }^{64}$ Oleh karena itu, Yehezkiel sama sekali tidak memberikan indikasi dalam pasal-pasal ini bahwa ia sedang membicarakan sesuatu yang akan terjadi dalam sebuah masa milenium yang akan mendahului kondisi kekekalan. ${ }^{65}$

Di samping itu, Berkoff menambahkan bahwa premilenial memasukkan diri ke dalam kesulitan yang berat dengan doktrin milenium mereka. Ia berpendapat bahwa sangatlah mustahil untuk memahami bagaimana bisa sebagian dari dunia lama dari masnuai berdosa bisa ada bersamasama dengan bagian dunia yang baru di mana orang-orang hidup dalam kemuliaan? Bagaimana orang kudus dalam tubuh kemuliaan bisa bersatu dengan orang berdosa dalam daging? Bagaimana mungkin orang kudus yang telah dimuliakan bisa hidup bersama dalam suasana penuh dosa dan di tengah-tengah kematian dan kehancuran?

Pasal dua puluh satu dari kitab Wahyu mengatakan bahwa Tuhan dan gereja yang ditebus akan menempati kedudukan mereka di bumi sesudah langit dan bumi diperbaharui. Akan tetapi, bagaimana mungkin hal ini dapat terjadi bila Kristus dan orang kudus tinggal di sana selama seribu tahun sebelum pembaharuan ini? Bagaimana mungkin orang berdosa dan orang kudus dalam daging bisa hadir dalam kemuliaan Kristus? Kaum Teologi

korban-korban persembahan dengan tujuan sebagai peringatan bagi kematian Kristus, jikalau Tuhan sendiri telah memberikan kepada ktia tanda lain sebagai peringatan yaitu Perjamuan Kudus?

${ }^{65}$ Tafsiran terhadap bagian ini yang sejalan dengan ajaran PB dan yang tidak mengandung permasalahan seperti pengertian korban peringatan dalam milennium adalah bahwa Yehezkiel sedang menggambarkan masa depan umat Allah yang penuh kemuliaan di zaman yang akan datang dengan menggunakan bahasa yang dimengerti oleh orang-orang Yahudi pada masa itu. Dengan demikian, rincian tentang Bait Allah dan korbankorbannya harus dimengerti bukan secara harafiah melainkan figuratif. 
Perjanjian menyimpulkan bahwa hal ini merupakan kekacauan yang saling tidak konsisten semata-mata. ${ }^{66}$

Keberatan selanjutnya ialah Alkitab tidak mengajarkan pemulihan politik bagi Israel melalui masa seribu tahun. Dispensasionalis menggunakan Yesaya 11:11-16 ${ }^{67}$ untuk mendukung gagasannya ini. Akan tetapi, hal-hal yang dinubuatkan dalam Yesaya merupakan kembalinya sisasisa umat Allah dari pembuangan di masa yang jauh di depan mereka. Bangsa Asyur disebutkan pertama dalam nats tersebut menunjukkan bahwa Yesaya menuliskan nubuatannya ini sesudah kerajaan Utara ditawan ke Asyur pada tahun 721 SM. Nubuat ini tergenapi secara harafiah ketika bangsa Israel kembali dari pembuangan pada abad ke enam SM. Yeremia 23:3, $7: 8^{68}$, Dispensasionalis mengatakan bahwa ini merupakan pemulihan akhir yang akan digenapi pada sesudah terjadinya kesusahan besar.

Akan tetapi, Hoekema mempertanyakan mengapa nubuat ini tidak dimengerti sebagai hal yang telah digenapi melalui kembalinya bangsa Israel dari tawanan pada abad ke enam SM? Bukankah Yeremia mengucapkan kata-kata tersebut sesaat

\footnotetext{
${ }^{66}$ Berkhof, Doktrin Akhir Zaman, 105-106.

${ }^{67}$ Nats ini berbunyi, "Pada waktu itu Tuhan akan mengangkat pula tangan-Nya (yang kedua kalinya) untuk menembus sisa-sisa umat-Nya yang tertinggal di Asyur dan di Mesir, di Patros, di Etiophia dan di Elam, di Sinear, di Hamat dan di pulau-pulau di laut". Nats ini berbicara mengenai sebuah gambaran nubuatan tentang kemuliaan dari kerajaan yang akan datang, yang akan ditegakkan ketika Anak Daud datang kembali.

${ }^{68}$ Nats ini berkata, "Dan Aku sendiri akan mengumpulkan sisa-sisa kambing domba-Ku dari segala negeri ke mana Aku mencerai-beraikan mereka dan Aku akan membawa mereka kembali ke padang mereka: mereka akan berkembang baik dan bertambah banyak (ay. 3). Sebab itu, demikianlah firman Tuhan, sesungguhnya, waktunya akan datang, bahwa orang tidak lagi mengatakan: Demi Tuhan yang hidup yang menuntun orang Israel keluar dari tanah Mesir, melainkan: Demi Tuhan yang hidup yang menuntun dan membawa keturunan kaum Israel keluar dari tanah utara dan
}

sebelum ditawannya kerajaan Yehuda ke Babel? Fakta bahwa Yeremia sendiri secara khusus menyebutkan kembalinya mereka dari pembuangan di Babel pada pasal berikutnya mendukung pernyataan bahwa hal ini merupakan peristiwa kembalinya bangsa Israel sebagaimana yang telah dinubuatkan di dalam pasal 23. ${ }^{69}$ Dengan demikian,

\section{KEBERATAN KONSEP PENGANGKATAN, KEBANGKITAN \& PENGHAKIMAN}

Keberatan keempat dikemukakan oleh Berkof. Pandangan dispensasionalisme bertentangan dengan penjelasan Alkitab mengenai peristiwa-peristiwa besar di masa depan yaitu kebangkitan, penghakiman terakhir dan akhir zaman.

Alkitab menyebutkan bahwa semua peristiwa itu terjadi secara bersamaan. Semua peristiwa itu bersamaan terjadi (Mat. 13:37-43, 47-50). Pemisahan antara yang baik dan yang jahat "pada akhir" dan bukan pada seribu tahun sebelumnya. ${ }^{70}$

Gagasan dispensasionalisme mengenai pengangkatan gereja secara "rahasia" yang tidak diketahui oleh orang non-Kristen

dari segala negerti ke mana Ia telah menceraiberaikan mereka, maka mereka akan tinggal di tanahnya sendiri (7-8).

${ }^{69}$ Sebab beginilah Firman Tuhan: Apabila telah genap tujuh puluh tahun bagi Babel, barulah Aku memperhatikan kamu. Aku akan menepati janji-Ku itu kepadamu dengan mengembalikan kamu ke tempat ini (Yer. 29:10). Di samping itu, perlu diperhatikan juga bahwa dalam pasal 24:5-6, yaitu pasal yang mengiktui 23:3, Yeremia dengan jelas menunjukkan kepada kembalinya Israel dari pembuangan di Babel (Kasdim): "Sama seperti buah ara yang baik ini, demikianlah Aku akan memperhatikan untuk kebaikannya orang-orang Yehuda yang Kubawa dari tempat ini ke dalam pembuangan, ke negeri orang-orang Kasdim. Maka Aku akan mengarahkan mata-Ku kepada mereka untuk kebaikan mereka, dan Aku akan membawa mereka kembali ke negeri ini ..."

${ }^{70}$ Louis Berkhof, Doktrin Akhir Zaman (Surabaya: Lembaga Reformed Injili Indonesia, 2001), 104105. 
berlawanan sama sekali dengan tujuan isi 1 Tesalonika 4:16-17. Bukanlah rahasia apabila Alkitab berbicara tentang "penghulu malaikat berseru", "sangkakala Allah berbunyi". Jika suara tersebut membangunkan orang mati, maka tentunya itu tidak mungkin merupakan suatu rahasia. $^{71}$

Di samping itu, tidak ada dasar dari Alkitab yang positif untuk menyebutkan akan adanya kebangkitan ganda dari orangorang mati. Alkitab tidak pernah membedakan adanya dua kebangkitan (orang benar dan orang fasik) yang terpisah selama 1000 tahun. Akan tetapi, kebangkitan umat Allah berbeda dengan kebangkitan orang yang tidak percaya dalam prinsip geraknya, natur esensialnya dan akhir terjadinya.

Dengan demikian, nats-nats Alkitab sama sekali tidak mengarah kepada kebangkitan ganda yang dikemukakan oleh kaum dispensasionalis. Alkitab dengan jelas mengatakan bahwa orang benar dengan orang durhaka akan dibangkitkan bersamasama seperti di dalam Dan. 12:2, Yoh. 5:2829; Kis. 24:15. Nats-nats ini tidak pernah berisi satu petunjuk sekecil apapun bahwa kedua peristiwa kebangkitan itu akan terpisah sejauh 1000 tahun.

Alkitab justru mengajarkan bahwa kebangkitan akan terjadi pada hari terakhir dan akan segera diikuti dengan penghakiman terakhir (Mat. 25:31-32; Yoh. 5:27-29; 6:39-40, 44-54; 11:24; Why 20:1115). ${ }^{72}$ Kaum dispensasionalis mempertahankan kebangkitan ganda berdasarkan Why. 20:4-6. Dalam nats ini, Yohanes menyebutkan adanya kebangkitan yang pertama. Secara langsung, banyak ahli yang berpendapat akan adanya kebangkitan yang kedua.

Berkoff menyangsikan bahwa di dalam nats ini membicarakan akan kebangkitan tubuh. Lagipula, istilah-istilah yang dipakai juga tidak menunjukkan akan

\footnotetext{
${ }^{71}$ Conn, Teologia Kontemporer, 133.

${ }^{72}$ Berkhof, Doktrin Akhir Zaman, 125.
}

adanya kebangkitan jasmani. Menurutnya, penulis kitab Wahyu tidak membicarakan mengenai pribadi-pribadi atau tubuh-tubuh yang dibangkitkan, tetapi tentang jiwa yang hidup dan memerintah bersama Kristus. ${ }^{73}$

Kaum dispensasionalis membagi penghakiman Allah bagi manusia ke dalam beberapa bagian ${ }^{74}$ :

1. Penghakiman orang-orang percaya. Hal ini terdapat di dalam 2 Kor. 5:10 bahwa gereja akan diadili kursi pengadilan atau bema Kristus. Pengadilan ini akan terjadi ketika gereja diangkat dari dunia yang bertujuan untuk memberikan pahala.

2. Pengadilan Israel terjadi sebelum kerajaan seribu tahun ditetapkan atau setelah pengangkatan gereja atau dipenghujung masa tribulasi di bumi.

3. Penghakiman bangsa-bangsa terjadi ketika Yesus datang yang kedua kali. Hal ini mendahului kerajaan seribu tahun yang bertujuan untuk menyaring mereka yang akan masuk ke dalam kerajaan seribu tahun.

4. Pengadilan di Takhta Putih Besar yaitu untuk mengadili kejahatankejahatan orang-orang fasik dan terjadi dipenghujung kerajaan seribu tahun.

Berkof menolak akan penghakiman Allah seperti yang di atas. Ia dengan tegas

mengatakan bahwa Alkitab selalu mengatakan bahwa penghakiman terakhir merupakan sebuah peristiwa tunggal. Alkitab mengajarkan bukan untuk menantikan hari-hari tetapi hari penghakiman (Yoh. 5:28-29, Kis. 17:31; 2 Pet. 3:7).

Di samping itu, Berkof juga menghimbau untuk selalu memperhatikan bahwa penghakiman bagi orang durhaka terjadi mengiringi parousia dan juga penampakan Kristus (2 Tes. 1:7-10; 2 Pet.

\footnotetext{
${ }^{73}$ Ibid., 127.

${ }^{74}$ Marantika, Eskatologi, 122-136.
} 
3:4-7). Akhirnya, Allah tidak menghakimi bangsa-bangsa sebagai bangsa di mana keputusan kekal dijatuhkan tetapi Allah hanya menghakimi individu.

Oleh karena itu, seseorang dapat memberikan tafsiran yang dapat diterima dan konsisten terhadap Mat. 25:31-46 apabila ia menyakini bahwa penghakiman yang disebutkan itu menunjuk kepada penghakiman universal bagi semua orang dan dihakimi sebagai individu bukan bangsa. ${ }^{75}$

\section{DAFTAR PUSTAKA}

[1] Bass, Clarence B. Backgrounds to Dispensationalism. Grand Rapids:

Eerdmans, 1960.

[2] Chafer, Lewis Sperry.

Dispensationalism. Dallas: Seminary Press, 1936.

[3] Chafer, Lewis Sperry. Systematic Theology. Texas: Dallas Seminary Press, 1947.

[4] Conner, Kevin J. \& Ken Malmin. Interpreting The Scriptures. Malang: Gandum Mas, 2004.

[5] Enns, Paul. The Moody Handbook of Theology 2. Malang: SAAT, 2004.

[6] Hoekema, Anthony A. Alkitab dan

Akhir Zaman. Surabaya: Momentum, 2004.

[7] Ladd, George Eldon. Theology Of the New Testament. Grand Rapids: Eerdmans, 1974.

[8] Menzies, \& Stanley M. Horton, Doktrin Alkitab. Malang: Gandum Mas, 1998.

[9] Marantika, Chris.

Eskatologi.Yogyakarta: Iman Press, 2004.
[10] Moulton, J.H. and George Milligan. The Vocabulary of the Greek Testament. Grand Rapids: Wm. B. Eerdmans Publishing Co., 1949.

[11] Pentecost, J. Dwight. Things to Come. Findlay, Ohio: Dunham, 1958.

[12] Peter, Eddy Peter. Teologi Perjanjian Versus Dispensasionalisme.Tangerang: STT International Philadelphia, 2004.

[13] Ramm, Barnard. Protestant Biblical Interpretation. Boston: W. A Wilde, 1956.

[14] Ryrie, Charles C. Dispensationalism Today. Chicago: Moody Press, 1965.

[15] The Oxford English Dictionary. Oxford University Press, 1933), III.

[16] Walvoord, John F. Major Bible Prophecies. Grand Rapids: Zondervan, 1991.

[17] Walvoord, John F. The Millennial Kingdom. Findlay Ohio: Dunham, 1958.

\footnotetext{
${ }^{75}$ Berkhof, Doktrin Akhir Zaman, 134-135.
} 